\title{
The Effect of Performance Based Budgeting and Internal Control Systems on Performance Accountability of Government Agencies: A Case Study In Banjarbaru City Inspectorates
}

\author{
Mujennah $^{1}$, Budi Artinah ${ }^{2}$, Safriansyah $^{3}$ \\ ${ }^{1,2,3}$ Sekolah Tinggi IImu Ekonomi Indonesia (STIEI) Banjarmasin
}

* Corresponding author: mujennah@stiei-kayutangi-bjm.ac.id

\begin{abstract}
The system of good governance is able to realize the governance of the country clean and free from Collusion and Nepotism Corruption (UU 28 year1998). One of the steps of the Banjarbaru City Inspectorates to realize Good Corporate Governance is through the transparency of performance accountability of government agencies in managing regional finances, most of which are funded by public funds. Performance accountability of government agencies presents budget allocations and realization for implementing key tasks in achieving performance indicators. The achievement of this performance indicator can be accounted for and realized through a performance-based budget. However, in its implementation, supervision, control, responsibility and assessment of performance accountability of government agencies is needed. This is where the role of the Internal Control System is in charge of carrying out oversight of the running of the government and the management of financial areas that are clean and responsible. The purpose of this study was to find out whether the Performance Based Budget and Internal Control System had an effect on the Performance Accountability of Government Agencies at Banjarbaru City Inspectorates. The sample used amounted to 39 respondents. The sampling technique is prurposive sampling. The analytical method used in this study is multiple regression analysis. The results of the study indicate that the implementation of the budget, budget reporting, control activities and monitoring (supervision) has an influence on Performance Accountability of Government Agencies . Budget planning, performance evaluation, control environment, risk assessment, information and communication have no effect on Performance Accountability of Government Agencies.
\end{abstract}

Keywords: Performance Based Budget, Internal Control System, Good Corporate Governance (Gcg), Performance Accountability of Government Agencies
ARTICLE INFORMATION

Received: 28 April 2019 Revised: 25 May 2019 Accepted: 30 June 2019

DOI: $10.31580 /$ jei.v6i3.924

\section{INTRODUCTION}

\section{Research Background and Problem}

A good system of Government (Good Governance) is a system of Government that can organise the governance of the country with clean and free KKN (corruption, Collusion and Nepotism). The embodiment of good governance certainly required the existence of a good performance measurement system, capable of implementing a system of reward and punishment, evaluate the efficiency, effectiveness, accountability in programs and activities, as well as being able to increase product performance. Performance accountability of government agencies includes financial accountability presents the allocation and the realization of the budget to achieve product performance indicators of government agencies. Through performance-based budget that will either close the desired performance results in the form of an optimum output. Continuous performance measurement will provide feedback, so that continuous improvement efforts will achieve success in the future (Bastian, 2006:275). Performance accountability of government agencies is an adequate accountability system, built and developed as a principal task of the implementation responsibility of government agencies as well as the management of resources in carrying out the policies and the program. (Presidential Regulation number 8 Year 2006). On the other hand to improve the achievement product performance of local governments that are realized through performance-based Budgets and compliance with the program and the policies against a performance accountability of government agency there needs to be supervision and assessment of system accountability that is appropriate, clear, measurable, effective, efficient, through a good the internal control system. This regional financial supervision is contained in Government Regulation No. 60 year 2008 concerning the Government's Internal Control System for the organization of tasks and organizational functions in order to provide adequate confidence that the activities have been implemented in accordance with predetermined benchmarks effectively and efficiently so that the Government can take in organizing clean and responsible. rom the results of the report year 2017 BPKP in Banjarbaru City Inspectorates regarding review of local Government Units Work Plan (unit of work devices area) obtained the findings of the existence of a wrong classification 
of expenditure account, unit price is not appropriate with the standard unit price, purpose of activities not aligned with the program, and still weak surveillance in particular follow up the findings of the Agency's Financial Examiner (BPK). According to the secondary data, the author can based on the table the budget realization based on events in the meet that: the total cost budgeted for activity of non formal education and training percentage acquired: $72.6 \%$, the budget for the evaluation Internal control system the Government as much as $48.55 \%$, follow-up of the BPK's findings as much as $77.8 \%$ this illustrates that the percentage of the budget for these activities is still weak, it showed in preparing the budget revenue and spending local governments (APBD) have not been in accordance with the regulatory in force and indicated the existence of a program or activity that has not been fully implemented. Looking at the various problems described above, and differences from several research results motivate researchers to conduct research on "The Effect of Performance-Based Budgeting and Internal Control Systems on Performance Accountability of Government Agencies" (Case Study in Banjarbaru City Inspectorates) by using nine variables in measuring budget implementation performance based, namely, budget planning (X1), budget implementation (X2), reporting or budget accountability (X3), and performance evaluation (X4) and Internal Control Systems (SPI) which include; control environment (X5), risk assessment (X6), control activities (X7), information and communication (X8) and supervision (X9) on the Performance Accountability of Government Agencies (Y).

\section{Research Objectives}

Based on the background and the problem the purpose of this research are:

1. To explain the effect of Budget Planning (X1) on Performance Accountability of Goverment Agencies in Banjarbaru City Inspectorates.

2. To explain the effect of Budget Implementation (X2) on Performance Accountability of Goverment Agencies in the Banjarbaru City Inspectorates.

3. To explain the effect of Reporting and Accountability (X3) on the Performance Accountability of Goverment Agencies in Banjarbaru City Inspectorates.

4. To explain the effect of Budget Evaluation (X4) on the Performance Accountability of Goverment Agencies in the Banjarbaru City Inspectorates.

5. To explain the effect of the Control Environment (X5) on the Performance Accountability of Goverment Agencies in the Banjarbaru City Inspectorates.

6. To explain the effect of Risk Assessment (X6) on the Performance Accountability of Government Agencies in the Banjarbaru City Inspectorates.

7. To explain the effect of Control Activities (X7) on Performance Accountability of Government Agencies in Banjarbaru City Inspectorates.

8. To explain the effect of Information and Communication (X8) on the Performance Accountability of Government Agencies in Banjarbaru City Inspectorates

9. To explain the effect of Supervision (X9) on the Performance Accountability of Government Agencies in Banjarbaru City Inspectorates

\section{LITERATURE REVIEW}

\section{The Agency Theory}

The Agency Theory can be explained using the concept of accountability agency theory, which broadly in the sense of accountability can be understood as a mandate holder party liability in this case the Government (agent) for accountability, presenting, reporting, and reveal all activities and activities into his responsibilities to the giver of the mandate in this community that is represented by the DPRD (principal) who has the right and authority to hold accountable

\section{Budgeting}

According to the National Budget on Governmental Accounting (NCGA) currently has become the Governmental Accounting Standards Board (GASB), Budgeting is a plan of financial operation, which includes estimated expenditure proposed, and the expected revenue sources to fund it in a certain time period (Bastian, 2006:164).

\section{Performance Based Budgeting}

Performance based Budgeting performance-based Budgeting is a Performance-oriented budgeting system output organization and closely related to the vision, mission, and strategic plan of the Organization Bastian (2006; 171). Performance budget is essentially a system of drafting and management of budget-oriented area on the achievement of results or performance. The performance reflects the efficiency and effectiveness of public services, which means a public interest-oriented (Mardiasmo, 2002:105).

The purpose of the application of performance-based budgeting is expected to:

1. Indicate the link between funding and performance achievements that will be reached (directly linkages between performance and budget)

2. Increase efficiency and transparency in the implementation of the (operational efficiency).

3. Increasing the flexibility and accountability units in carrying out the tasks and budget management (more flexibility and accountability).

\section{The Benefits of Performance-Based Budgeting}

The Ministry of Finance of the Republic of Indonesia Financial education and training Agency (2008) States that the application of performance-based budget will provide benefits in the implementation of financial management in the framework of the Organization of the national tasks, as follows : the first performance-based budget allows allocating limited resources to finance the activities of the priority the Government so that the Government's purpose can be achieved efficiently and effectively. Second, the application of performance-based budgeting is important to the implementation of the Government's activities are transparent. A clear budget, and also a clear output, as well as the existence of a clear relationship between expenditures and outputs to be achieved. The third budget allows for an increase in the efficiency of the administration. This is very much different when compared with when budgeting focus fixed on input.

\section{Performance Accountability of Government Agencies}

The decision of the head of LAN no. 239/IX/6/8/2003 on guidelines for the preparation of Reporting performance accountability of government agencies, explaining that the performance accountability of government agencies is the embodiment of an obligation of government agencies to account for success and failure of the implementation of the vision and mission of the Organization in the intended objectives through a periodic system of accountability

\section{Internal Control System}


Definition of Internal Control according to the Committee of Sponsoring Organizations (COSO) As quoted by Romney \& Steinbart (2000) as follows: "Internal control is a process implemented by the board of directors, management, and other personnel, designed to provide reasonable assurance that control objectives are achieved with regard to the following:

1. Effectiveness and efficiency of operations.

2. Reliability of financial reporting

3. Compliance with applicable laws and regulate

\section{ENVIRONMENTAL CONTROL (CONTROL ENVIRONMENT)}

There are six factors contained in control environtment: integrity and ethical values commitment to competence of the Board of Directors and the audit Committee), management philosophy and operating style, organizational structures, assignment of authority and responsibilities, policies and procedures and human resources practices

\section{RISK ASSESSMENT}

This component assesses the extent to which the impact of an event can interfere with the achievement of the company's objectives

\section{CONTROL ACTIVITIES}

According to Arens, Alvin a, James k. Loebbecke and (2011:380-384) control activities can be grouped in several categories including: a clear Separation of duties, Proper authorization of transactions and activities, Adequate documents and records, Physical control of assets and records.

\section{INFORMATION AND COMMUNICATION (INFORMATION AND COMMUNICATIONS)}

This component emphasizes the communication and delivery of good and relevant information to the party or parties intern and ektsern so happens a good control in the company. Communication that is giving a clear understanding of the roles and responsibilities of each individual. Communications should be run effectively from both the organizational structure of the top level management organization down.

\section{OVERSIGHT (MONITORING)}

Supervision is a process of assessing the quality of the performance of the internal control structure. Through supervision carried out periodically, management can ensure that the existing risks can be controlled at a level acceptable to management

\section{Earlier Research and the formulation of Hypothesis}

\section{EFFECT OF BUDGET PLANNING ON PERFormance ACCOUNTABILITY OF LOCAL GOVERNMENT AGENCIES}

Linkages between performance-based budgeting with performance accountability of local government agencies can be seen in the statement Bastian (2005:54) that efforts to create performance-based budget management are expected to be able to meet various demands and needs of the community, namely the spirit of decentralization, democratization, transparency and accountability in the process of administering the government in general and the process of regional financial management in particular. Muda (2005) through his research showed that there is influence of budget planning against the performance accountability of government agencies at the Secretariat of the City Municipality of South Jakarta and there is the influence of the implementation of the
Budget against Performance accountability of government agencies at the Secretariat of the municipality of South Jakarta City. From the results of testing hypotheses obtained that $t$ count $27.697>t$ table 1.645. There is the influence of budget planning and Budget Execution simultaneously on the performance accountability of government agencies at the Secretariat of the City Municipality of South Jakarta. It is also comparable to the research that has been done before like Seto (2018), Laura (2016), Haspiarti (2012) and Muda (2005) concerning the influence of performance-based budget planning against the performance accountability of government agencies shows the results of a performance-based budget planning that influence on performance accountability of government agencies.

$\mathrm{H} 1$ : Budget planning performance accountability to government agencies

\section{EFFECT OF BUDGET IMPLEMENTATION ON PERFORMANCE ACCOUNTABILITY OF GOVERNMENT AGGENCIES}

The implementation of the Budget by the heads of the Regional official work unit (SKPD) executed after the execution of the Budget Documents of the Regional official work unit (SKPD) are defined by officials of the regional finance manager (PPKD) with approval. Based on the results of research conducted by Seto (2018), Laura (2016), conducted a study entitled "the effect of the application of performance-based budgeting system and financial reporting on performance accountability of government agencies (case study on Bandung City Government), the results of his research shows the implementation of the budget of the positive and significant effect against the performance accountability of Government

H2: implementation (Implementation) Budget performance accountability to government agencies

\section{EFFECT OF BUDGETS REPORTING ON PERFORMANCE ACCOUNTABILITY OF GOVERNEMENT AGENCIES}

Reporting in this case include the magnitude of the budget allocation of work units, the magnitude of the budget that had been issued along with the achievement of the work or activity or program that has been implemented. The head of the Regional official work unit (SKPD) develop and report periodically to the cash flow of the head region, the report compiled and presented in accordance with the Government regulations that govern accounting standards of governance. Report on implementation of the budget of the Regional official work unit (SKPD) accountability includes; Report a budget realization, the balance, and notes on the financial statements of of the Regional official work unit (SKPD). Based on the results of research conducted by Raissa, Ceni (2016), Laura (2016), Haspiarti (2012) and Muda (2005) shows that the effect on budgetary reporting has an effect on performance accountability of Government Agencies .

H3: Budget reporting affects the Performance Accountability of Government Agencies

\section{EFFECT OF PERFormance EVALUATION ON PERFormance ACCOUNTABILITY OF GOVERNMENT AGENCIES}

Accountability module of government agencies (2007), the purpose of performance evaluation is that the organization concerned knows the achievement of realization, progress and constraints encountered or the reasons for not achieving performance in order to achieve the planned mission so that the agency can improve its performance in the future will come, so that with a well-conducted performance evaluation it is expected that it will be able to improve the performance accountability of government agencies. This is in line with the results of research conducted by Seto (2018), Raissa, Ceni 
(2016), Laura (2016), Haspiarti (2012) and Muda (2005), the results of the study indicate that performance evaluation has a positive and significant effect on government performance accountability

H4: Budget Performance Evaluation has an effect on Government Agency Performance Accountability

\section{EFFECT OF ENVIRONMENT CONTROL ON PERFORMANCE ACCOUNTABILITY OF GOVERNMENT AGENCIES}

Haerul (2017) in her research showed that the competence of human resources and the role of regional inspectorates had no significant effect on the quality of regional financial statements,, while internal control and utilization of technology of information technology had a significant effect on the quality of regional financial statements. In a study conducted by Fajar Bayu (2016) regarding the factors that influence the performance accountability of government agencies stated that the results of the study stated that the government internal control system had a significant positive effect on the performance accountability of government agencies. Likewise with the research of Arif, Lola, Diarespati (2017), Ummu, Abdu (2013) states that the control environment has a positive and significant effect on the performance accountability of government agencies from these results the researchers propose the following hypotheses:

H5: The Control Environment has an effect on Performance Accountability Of Government Agencies .

\section{EFFECTS OF RISK ASSESSMENT ON PERFORMANCE ACCOUNTABILITY OF GOVERNMENT AGENCIES}

Arens (2011) explains that risk assessment will assess the extent to which the impact of an event can disrupt the achievement of company goals. The company must be able to manage the risks it faces. In addition to being able to manage and conduct risk assessments, companies must be able to establish mechanisms to identify, analyze and manage these risks properly. Based on research conducted by Haerul (2017), Fajar Bayu (2016), Hannum (2013) and Ummu, Abdul (2013) states that risk assessment has a positive and significant effect on the performance accountability of government agencies, from these results the researchers propose the following hypotheses:

H6: Risk Assessment has an effect on Government Agency Performance Accountability

\section{EFFECT OF CONTROL ACtIVITIES ON PERFORMANCE ACCOUNTABILITY OF GOVERNMENT AGENCIES}

Components of activities (activities) of control play a role in the preparation of policies and procedures to ensure that the risk response is carried out effectively and the management's control objectives can be achieved. Arens (2011 divides control activities into five groups, namely: a) Separation of clear tasks, b) Proper authorization of transactions and activities. c) Sufficient documents and records, d) Independent checks on implementation and e) Physical control of assets and records. Arif, Lola, Diarespati (2017), Ummu, Abdul (2013) and Hannum (2013) stated that control activities have a positive and significant effect on the performance accountability of government agencies from the results of the researchers proposing the following hypotheses:

H7: Control Activities have an effect on Government Agency Performance Accountability

\section{EFFECTS OF INFORMATION AND COMMUNICATION ON THE} Performance Accountability of Government Agencies
Information systems convert inputs in the form of transactions with various types of transaction processing, both financial and non-financial. Information and communication systems are methods and records for recording, processing, summarizing and reporting transactions and the results of responsibility for the use of assets. Based on research by Arif, Lola, Diarespati (2017), Ummu, Abdul (2013) and Hannum (2013) states that information and communication have a positive and significant effect on the performance accountability of government agencies from these results the researchers propose the following hypotheses:

H8: Information and Communication has an effect on the Performance Accountability of Government Agencies at Banjarbaru City Inspectorates

\section{EFFECT OF SUPERVISION ON PERFORMANCE ACCOUNTABILITY OF GOVERNMENT AGENCIES}

Supervision according to Coso in Arens (2011) is a process of assessing the quality of the performance of internal control structures. Through supervision carried out periodically, management can ensure that the existing risks can be controlled at a level that can be accepted by management and to see that mitigation has been carried out according to the wishes of the company or still needs to be improved to suit environmental changes through effective supervision, internal reporting and audit. To carry out good supervision, management evaluates every policy and procedure related to system policies and the company's internal control structure on a regular basis, so the system can run properly. The management in carrying out supervision effectively, providing such information must be timely, accurate, complete and in accordance with the incident. Ira Halidayati (2014) in her research showed the results that internal supervision had a significant positive effect on the performance of local governments. Likewise, based on research by Arif, Lola, Diarespati (2017), Ummu, Abdul (2013) and Hannum (2013) stating that the internal control system has a positive and significant effect on the performance accountability of government agencies from these results the researchers put forward the following hypothesis:

H9: Supervision affects the Performance Accountability of Government Agencies

\section{METHODOLOGY}

\section{Data Types}

The type of data in this study is the type of subject data obtained in the form of opinions, attitudes, experiences and characteristics of the respondents who were the subjects of the study.

\section{Data Sources}

The data sources used in this study are: primary data in the form of respondents' answers to question items contained in 5 (five) research instruments, namely the application of performance-based budgets measured by four variables, namely (budget planning, budget execution, reporting or budget accountability, performance evaluation and performance accountability of government agencies. The methods used in the design of this research is the multiple regression analysis with quantitative methods in which the author tries to explain, summarizes the conditions of significant variables and objects found at the time of research.

\section{Techniques and Data collection}

Data collection is done through questionnaire surveys of the Regional Work Unit in the scope of the Banjarbaru City 
Inspectorates. The measurement scale and number of questionnaire questions can be seen in Table 1.

Table 1. Model Partial Test Results (test $t$ )

\begin{tabular}{|c|c|c|c|}
\hline Variabel & Indicator & $\begin{array}{l}\text { No. } \\
\text { Ques } \\
\text { tions }\end{array}$ & $\begin{array}{l}\text { Measu } \\
\text { rement } \\
\text { Scale }\end{array}$ \\
\hline \multirow[t]{5}{*}{$\begin{array}{l}\text { The System of } \\
\text { Internal Control }\end{array}$} & $\begin{array}{l}\text { 1. Control Environment } \\
\left(X_{1}\right)\end{array}$ & $1-6$ & Likert \\
\hline & 2. Risk Assessment $\left(X_{2}\right)$ & 7 & Likert \\
\hline & 3. Control Activities $\left(X_{3}\right)$ & 8 & Likert \\
\hline & $\begin{array}{l}\text { 4. Information and } \\
\text { Communication }\left(\mathrm{X}_{4}\right)\end{array}$ & $9-10$ & Likert \\
\hline & 5. Supervison $\left(X_{5}\right)$ & $11-18$ & Likert \\
\hline \multirow{4}{*}{$\begin{array}{l}\text { Performance- } \\
\text { Based } \\
\text { Budgeting }\end{array}$} & 6. Budget Planning $\left(\mathrm{X}_{6}\right)$ & $19-27$ & Likert \\
\hline & $\begin{array}{l}\text { 7. Implementation and } \\
\text { execution of the budget } \\
\left(\mathrm{X}_{7}\right)\end{array}$ & $28-31$ & Likert \\
\hline & $\begin{array}{l}\text { 8. Reporting and } \\
\text { Accountability Budget } \\
\left(\mathrm{X}_{8}\right)\end{array}$ & $32-35$ & Likert \\
\hline & $\begin{array}{l}\text { 9. Performance } \\
\text { Evaluation }\left(X_{9}\right)\end{array}$ & $36-41$ & Likert \\
\hline Performance & 10. Performance & $42-51$ & Likert \\
\hline $\begin{array}{l}\text { Accountability of } \\
\text { Government } \\
\text { Agencies }\end{array}$ & $\begin{array}{l}\text { Accountability of } \\
\text { Government Agencies } \\
\text { (Y) }\end{array}$ & & \\
\hline
\end{tabular}

\section{Population and Samples}

\section{Population}

Population is the overall symptoms or unit wants to canvassed. According to Sugiyono (2005:72) population is a generalization of an object or subject that has certain qualities and characteristics set by the researchers to learn and then drawn the conclusion. The population used in this study is all Regional Work Units at the Inspectorate of the City of Banjarbaru. So the population of the study is all people who directly work at the Banjarbaru City Inspectorate. Namely 65 civil servants.

\section{SAMPLES}

Sampling technique is a sampling technique (Sugiyono, 2005: 73). The sampling technique used for performancebased budget variables and public accountability is probability sampling. According to Prasetyo and Jannah (2010: 122) that probability samples are a sampling technique based on each member having the same opportunity to be chosen. The type of probability sampling chosen is purposive sampling. The determination of samples is taken by characteristics. The population of 65 Regional Work Units, 39 samples will be taken.

\section{Testing the Validity of Data}

Validity of the test used to measure the validity of a questionnaire. A questionnaire is said to be valid if the questions on the questionnaire were able to reveal something that will be measured by the questionnaire. The validity of the testing done by doing the bilvariate correlation between each score indicator with a total score of invalid constructs. Bilvariate correlation analysis results by looking at the output of the Pearson Correlation (Ghozali, 2005). The criteria if the value of the sig (2-tailed) on a total score of invalid constructs $<0.05$ item questions or statements said invalid.

\section{Test Reliability}

Data reliability test is by looking at the value of cronbach.s alpha. If the value is cronbach. alpha is greater than 0.60 so the questions or statements on each of the research variables are declared reliable.

\section{Multiple Linear Regression Analysis}

Regression analysis is often used as one of the analytical tools to make projections. This is based on the fact that the value of a variable can be influenced by one or more changes in other variables. By using regression analysis the coefficients for each independent variable will be obtained. Multiple linear regression aims to determine the functional relationship between independent variables together on the dependent variable. The form of multiple linear regression equation according to (Sugiyono, 2011), as follows:

$$
Y=\beta 0+\beta 1 X 1+\beta 2 X 2+\beta 3 X 3+\beta 4 X 4+\beta 5 X 5+\beta 6 X 6+
$$$$
\beta 7 X 7+\beta 8 X 8+\beta 9 X 9
$$

\section{Model Feasibility Test}

Hypothesis testing in this study was carried out after first conducting a feasibility test model or more popularly referred to as the $F$ test. $F$ test (Simultaneous model test) is the initial stage of identifying the regression model that is estimated to be feasible or not. The model that is feasible means that the model can be used to explain the influence of independent variables on the dependent variable. If the value of $F$ count is greater than $F$ table at the level of confidence $\alpha=0.05$ or the probability value Fcount (sig) has a value smaller than 0.05 , it can be said that the estimated regression model is feasible.

\section{Hypothesis Test (t-test)}

This study tested three hypotheses are all partial hypothesis. So this research hypothesis testing using the test $t$. $t$ in multiple regression Test was intended to test whether the parameters (coefficient of regression and constants) alleged to mengestimasi multiple regression equation or model is already a parameter that is right or not. If the value of thitung is greater than the value of ttabel on level of significance Criteria is done if the thitung is greater than $t$ tabel at $\alpha=0.05$ level of confidence or probabilitias value t calculate (sig) have a value of less than 0.05 , then $\mathrm{HO}$ (from the free variables) denied or $\mathrm{Ha}$ (from the free variables) are accepted. In other words that the free variable (the count of $t$ ) effect significantly to the dependent variable. The hypothesis developed in this study shows that there is a functional or causal relationship between the application of performance-based budgets as independent variables with local government agencies performance accountability as the dependent variable. This hypothesis is rejected or received can be seen from the significance levels obtained after processing of data is done with the help of SPSS software 24.0 for windows. If the rate of significance gained less than $0.05 \mathrm{Ha}$ then accepted and $\mathrm{HO}$ is rejected. Conversely, if rates gained significance greater than $0.05 \mathrm{Ha}$ then rejected and $\mathrm{HO}$.

\section{Framework Conceptual Research}

A conceptual framework for research can be seen in Figure 1. 


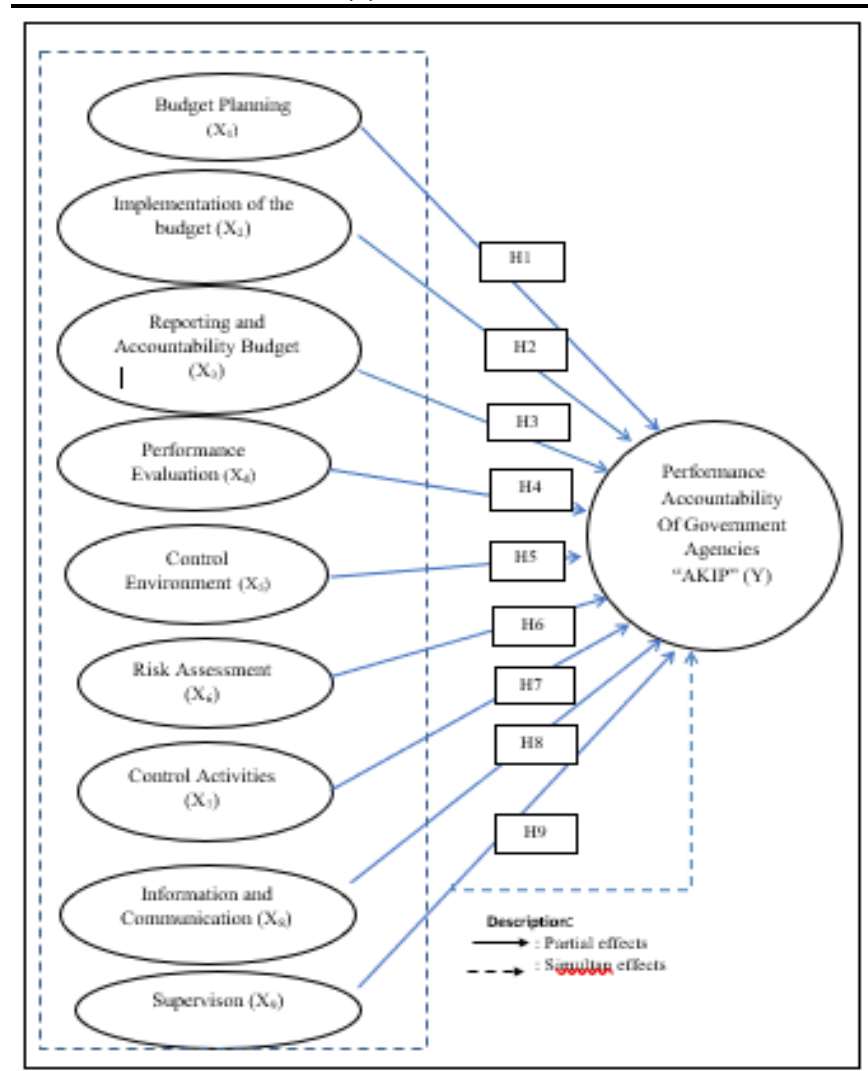

Fig1. Conceptual Framework

\section{RESULTS AND FINDINGS}

\section{Test for Validity}

The value of $r$ table with $n=39$ at significance of $5 \%$, it is found that the value of $r$ table is 0.308 indicating that all item statements in the research instrument used have numbers calculated $r$ values greater than $r$ table. This means that all statement items are valid. Test the validity of this study can be seen in Table 2.

Table 2. Model for Validity Test Results

\begin{tabular}{|c|c|c|c|c|c|}
\hline No & Variabel & $\begin{array}{l}\text { Num } \\
\text { ber } \\
\text { of } \\
\text { Items }\end{array}$ & $\begin{array}{l}r \\
\text { Table }\end{array}$ & $\begin{array}{l}\mathbf{r} \\
\text { count } \\
\text { (Koefe } \\
\text { sien } \\
\text { Correl } \\
\text { ation) }\end{array}$ & $\begin{array}{l}\text { Descri } \\
\text { ption }\end{array}$ \\
\hline 1 & Budget Planning & 6 & 0.308 & 0.627 & Valid \\
\hline 2 & $\begin{array}{l}\text { Implementation } \\
\text { and execution of } \\
\text { the budget }\end{array}$ & 1 & 0.308 & 0.467 & Valid \\
\hline 3 & $\begin{array}{l}\text { Reporting and } \\
\text { Accountability } \\
\text { Budget }\end{array}$ & 1 & 0.308 & 0.39 & Valid \\
\hline 4 & $\begin{array}{l}\text { Performance } \\
\text { Evaluation }\end{array}$ & 2 & 0.308 & 0.515 & Valid \\
\hline 5 & $\begin{array}{l}\text { Control } \\
\text { Environment }\end{array}$ & 8 & 0.308 & 0.833 & Valid \\
\hline 6 & Risk Assessmen & 9 & 0.308 & 0.781 & Valid \\
\hline 7 & Control Activities & 4 & 0.308 & 0.596 & Valid \\
\hline 8 & $\begin{array}{l}\text { Information and } \\
\text { Communication }\end{array}$ & 4 & 0.308 & 0.896 & Valid \\
\hline 9 & Supervison & 6 & 0.308 & 0.783 & Valid \\
\hline 10 & $\begin{array}{l}\text { Performance } \\
\text { Accountability } \\
\text { of Government } \\
\text { Agencies }\end{array}$ & 10 & 0.308 & 0.79 & Valid \\
\hline
\end{tabular}

\section{Test Reliability}

The instrument reliability testing in this study used the Cronbach's Alpha technique. Reliability assessment criteria is if the reliability coefficient results are at least 0.6 , the research instrument is reliable (Sugiyono, 2014: 220). The following is a recapitulation of the results of the instrument reliability. showed that all variables in the research instrument used had Cronbach's Alpha numbers above 0.6. This means that the research instruments used are reliable. Reliability test results can be seen in Table 3.

Table 3. Model for Reliability Test Results Of A Research Instrument

\begin{tabular}{lllll}
\hline No. & Variabel & $\begin{array}{l}\text { Number } \\
\text { Of Items }\end{array}$ & $\begin{array}{l}\text { Cronbach' } \\
\text { s Alpha }\end{array}$ & $\begin{array}{l}\text { Descrip } \\
\text { tion }\end{array}$ \\
\hline 1. & $\begin{array}{l}\text { Performance- } \\
\text { Based Budgeting }\end{array}$ & 4 & 0.895 & Reliabel \\
2. & $\begin{array}{l}\text { Internal Control } \\
\text { System }\end{array}$ & 5 & 0.879 & Reliabel \\
3. & $\begin{array}{l}\text { Performance } \\
\text { Accountability Of } \\
\text { Government } \\
\text { Agencies }\end{array}$ & 1 & 0.938 & Reliabel \\
\hline
\end{tabular}

\section{Multiple Regression Analysis}

Multiple Regression equations obtained from the influence of the variables $(X 1)$ budget planning, implementation of the budget (X3), the reporting of budget (X4), performance evaluation (X6), environmental Control (X5), risk assessment (X6), Control Activities (X7), Information and communication (X8), and monitoring (X10) on the performance accountability of government agencies $(Y)$ is as follows. The results of multiple linear regression can be seen at table 4.3.

$$
\begin{aligned}
Y= & 30,318+0,599 X 1+(-4,738) X 2+3,254 X 3+1,167 X 4 \\
& +(-0,179) X 5+(-0,115) X 6+(1,294) X 7+(-0,211) X 8+ \\
& (-0,426) X 9
\end{aligned}
$$

\begin{tabular}{|c|c|c|c|c|}
\hline Model $\quad \mathbf{R}$ & $\begin{array}{l}\text { R- } \\
\text { Square }\end{array}$ & $\begin{array}{l}\text { Adjusted } \\
\text { R- } \\
\text { Square }\end{array}$ & $\begin{array}{l}\text { Std. } \\
\text { Error of } \\
\text { the } \\
\text { Estimate }\end{array}$ & $\begin{array}{l}\text { Durbin- } \\
\text { Watson }\end{array}$ \\
\hline $0.837^{\mathrm{a}}$ & 0.701 & 0.608 & 1.491 & 1.779 \\
\hline \multicolumn{5}{|c|}{$\begin{array}{l}{ }^{\mathrm{a}} \text { Predictors: (Constant), surveillance/Monitoring, implementation of the budget, } \\
\text { internal control Environment, Risk Assessment, information and communication, } \\
\text { reporting a budget, budget planning, Budget, evaluation of Control Activity } \\
\text { b Dependent Variable: Performance Accountability Of Government Agencies }\end{array}$} \\
\hline
\end{tabular}

Table 4. Model Summary for Multiple Regression Analysis

Testing the hypothesis (partial test) is done using the t-test which is done to find out whether the independent variables are significant or not to the regression model. This t-test is done by looking at the probability value (sig.) Below 0.05 or comparing tcount to $\mathrm{t}$ table. The table value indicated by $\mathrm{df}=30$ with $\mathrm{a}$ level of trust (sig.) $A=5 \%$ is 2,045 .

\section{Model Feasibility Testing}

Based on the Table 5 can be seen that the regression models showed a significant result with probability values (SIGs.) $\mathrm{F}<0.05(0.000<0.05)$, so that the model used in the analysis it deserves.

\section{Discussion}

The results of the analysis that had been featured on these shows implementation of Budget (X2), Reporting or Budget Accountability (X3), Control Activity (X7) and Monitoring (X9) 
have a significant effect on AKIP (Y). Whereas, Budget Planning (X1), Performance Evaluation (X4), Risk Assessment (X5), Information and communication (X8) have no effect significantly to AKIP (Y) in Banjarbaru City Inspectorate, South Kalimantan.

\begin{tabular}{|c|c|c|c|c|c|c|}
\hline \multicolumn{2}{|c|}{ Model } & \multirow{2}{*}{$\begin{array}{l}\begin{array}{l}\text { Sum of } \\
\text { Squares }\end{array} \\
151.392 \\
\end{array}$} & \multirow{2}{*}{$\begin{array}{l}\mathbf{d f} \\
9\end{array}$} & \multirow{2}{*}{$\begin{array}{l}\text { Mean } \\
\text { Square } \\
16.821\end{array}$} & \multirow{2}{*}{$\begin{array}{l}\mathbf{F} \\
7.562\end{array}$} & \multirow{2}{*}{$\begin{array}{l}\text { Sig. } \\
.000^{\circ}\end{array}$} \\
\hline 1 & Regression & & & & & \\
\hline & $\begin{array}{l}\text { Residual } \\
\text { Total }\end{array}$ & $\begin{array}{l}64.505 \\
215.897\end{array}$ & $\begin{array}{l}29 \\
38\end{array}$ & 2.224 & & \\
\hline
\end{tabular}

${ }^{\mathrm{a}}$ Dependent Variable: AKIP

${ }^{\mathrm{b}}$ Predictors: (Constant), surveillance/Monitoring, implementation of the budget, internal control Environment, Risk Assessment, information and communication, reporting a budget, budget planning. Budget, evaluation of Control Activity

\section{EfFect of Budget PlanNing on PeRformance AcCOUNTABILITY OF GOVERNMENT AGENCIES}

The test results show that budget planning does not have a significant effect on AKIP at the Banjarbaru City Inspectorates. This is proven statistically by the value of $\mathrm{t}$-count $(1.755)<\mathrm{t}$ table 2.042 and the significance value of $0.090>0.05$, indicating that internal control does not have a positive and insignificant effect. Thus it can be concluded that when budget planning is carried out better or bigger, it will inversely proportionally account the performance of government agencies. The results of this study are in line with the research by Raissa, and Ch Cemi Kurniawan (2016) with the title Effect of Performance-Based Budgeting on Performance Accountability of Government Agencies in the Regional Work Unit of Magelang Regency. The results of his research show that Budget Planning does not have a significant effect on the Performance Accountability of Government Agencies

\section{EFFECT OF BUDGET IMPLEMENTATION ON PERFORMANCE ACCOUNTABILITY OF GOVERNMENT AGENCIES}

The test results show that the implementation of the budget has an influence on AKIP in the Inspectorate of the City of Banjarbaru. Based on the results of the comparison of tcount with t table, budget implementation has a significant effect on AKIP at the Banjarbaru City Inspectorate in South Kalimantan. This is proved statistically by the value of $t$ count $(-2,938)<t$ table 2.045 and a significance value of $0.006<0.05$. This result is in line with Haspiarti and Seto's research (2018) with the title Effect of Performance-Based Budgeting on Performance Accountability of Government Agencies, the results of his research indicate that there is influence and significance for the implementation and implementation of the budget for AKIP.

\section{EFFECTS OF BUDGET REPORTING ON PERFORMANCE ACCOUNTABILITY OF GOVERNMENT AGENCIES}

The test results show that budget reporting has an influence on the Performance Accountability of Government Agencies in the Inspectorate of the City of Banjarbaru. Based on the results of the comparison of tcount with t table, the results obtained statistically the value of $t$ count (3.001)> t table 2.045 and significance value $0.005<0.05$ means that reporting and budgetary accountability have a positive and significant effect on AKIP in the Banjarbaru City Inspectorate of South Kalimantan. This is in line with the research that has been investigated by Seto W (2018), Raissa (2016), Haspiarti (2012), and Muda (2005). The results of the study indicate that budget reporting has a positive effect on the Performance Accountability of Government Agencies. It can be concluded that the implementation of reporting and accountability of the budget at the Inspectorate of the city of Banjarbaru has been well implemented so as to increase the Performance Accountability of Government Agencies.

\section{EFFECT OF PERFORMANCE EVALUATION ON PERFORMANCE ACCOUNTABILITY OF GOVERNMENT AGENCIES}

The test results showed that performance evaluation did not influence AKIP at the Banjarbaru City Inspectorates. Based on the results of the performance evaluation test, it did not significantly affect AKIP at the Banjarbaru City Inspectorate in South Kalimantan. This can be seen from the ratio of tcount to ttable, obtained statistically the value of $t$ count $(1,649)<t$ table 2,045 and significance value of $0.110>0.05$ means this is in line with the research conducted by Seto (2018), Raissa, et al (2016), Laura (2016), Haspiarti (2012) and Muda (2005) who stated that performance evaluation has a positive but not significant effect on AKIP. With a good performance evaluation, every achievement of realization, progress, performance of government agencies will be able to improve the Performance Accountability of Government Agencies in overcoming every obstacle and the elements of not achieving the organization's mission and vision.

\section{EFFECTS OF THE CONTROL ENVIRONMENT ON PERFORMANCE ACCOUNTABILITY OF GOVERNMENT AGENCIES}

The test results show that the control environment does not have a significant influence on the Performance Accountability of Government Agencies. Based on the results of performance evaluation testing does not significantly influence the Performance Accountability of Government Agencies in Banjarbaru City Inspectorate, South Kalimantan. This can be seen from the ratio of $t$ count to $t$ table, obtained statistically the value of $t$ count $(-1,400)<t$ table 2,045 and the significance value of $0.172>0.05$. Through good internal control, company management can achieve company goals and objectives. From the results of the study it can be concluded that the Inspectorate of the City of Banjarbaru must review again about the components of the control environment including: a) Commitment to integrity and ethical values, b) Management commitment to competencies, c) Leadership Philosophy and Operating Style, d) Organizational Structure, e ) Participation of the Board of Commissioners and Audit Committee and f) Policies and Practices of Human Resources in improving the Performance Accountability of Government Agencies .

\section{EFFECTS OF RISK ASSESSMENT ON PERFORMANCE ACCOUNTABILITY OF GOVERNMENT AGENCIES}

The test results show that the risk assessment has less influence on AKIP at the Banjarbaru City Inspectorates. From the results of the comparison of tcount with ttable, the results obtained statistically are the value of t count $(-0.822)<t$ table 2.045 and the significance value of $0.418>0.05$. Based on these results the risk assessment did not have a significant effect on AKIP at the Banjarbaru City Inspectorate in South Kalimantan. This is not in line with the research of Hannum (2013) and Santha (2016). From the results of the study it can be concluded that the Banjarbaru City Inspectorate must further improve the system in risk assessment so as to minimize the risk of Banjarbaru City Inspekotar in achieving transparent and responsible AKIP in order to achieve the 2016-2020 Strategic Plan vision and mission.

\section{EFFECT OF CONTROL ACTIVITIES ON PERFORMANCE ACCOUNTABILITY OF GOVERNMENT AGENCIES}

The test results show that control activities have a positive and significant influence on the Performance Accountability of Government Agencies in the Inspectorate of the City of 
Banjarbaru. This is evidenced by the results of the ratio of tcount to ttable, obtained statistically the value of $t$ count (4.172)> t table 2.045 and the significance value of 0.000 $<0.05$. This is in line with the results of research by Hannum (2013), Santha, et al (2016), Fajar Bayu (2016) which states that Control Activities which are elements of SPI positively and significantly affect the Performance Accountability of Government Agencies in Banjarbaru City Inspectorate, South Kalimantan. From the results of the research, the Banjarbaru City Inspectorate has carried out good control activities on the Performance Accountability of Government Agencies.

\section{EFFECTS OF INFORMATION AND COMMUNICATION ON PERFORMANCE ACCOUNTABILITY OF GOVERNMENT AGENCIES}

The test results show that information and communication have no effect on AKIP at the Banjarbaru City Inspectorates. This is evidenced by the results of the ratio of tcount to ttable, obtained statistically the value of $t$ count $(-0.702)>t$ table 2.042 and the significance value of $0.489>0.05$. From the results of information and communication research at the Banjarbaru City Inspectorate, it has not run effectively and efficiently, by providing easy access to information and communication in the Banjarbaru City Inspectorate, the implementation of Government Agency Performance Accountability will be easier, faster, more effective and efficient.

\section{EFFECTS OF MONITORING ON PERFORMANCE ACCOUNTABILITY OF GOVERNMENT AGENCIES}

The test results show that monitoring has a significant influence on AKIP at the Banjarbaru City Inspectorates. Based on the results of the comparison of tcount with t table, the results obtained are statistically the value of $t$ count $(-1,986)>t$ table 2,042 and a significance value of $0.005<0.05$. This is in line with the research conducted by Hannum (2013), Santha Julia, et al (2016), Fajar (2016) which states that one of the components of SPI namely monitoring significantly influences the Performance Accountability of Government Agencies. From the results of the study it was found that the Inspectorate of the City of Banjarbaru had carried out good monitoring so that it was able to improve the performance accountability of government agencies.

\section{CONCLUSIONS}

Based on the results of hypothesis testing using multiple regression test, can be obtained at the following conclusions,

1. Budget Planning does not have a significant effect on the performance accountability of government agencies in Banjarbaru City Inspectorates.

2. Budget implementation has a significant effect on the performance accountability of government agencies in Banjarbaru City Inspectorates.

3. Budget reporting has a significant effect on agency performance accountability in Banjarbaru City Inspectorates.

4. Performance evaluation has no significant effect on agency performance accountability in Banjarbaru City Inspectorates.

5. The control environment does not have a significant effect on the performance accountability of government agencies in Banjarbaru City Inspectorates.

6. Risk Assessment does not have a significant effect on the performance accountability of government agencies in Banjarbaru City Inspectorates.

7. Control activities have a significant effect on the performance accountability of government agencies in Banjarbaru City Inspectorates.
8. Information and communication does not have a significant effect on the performance accountability of government agencies in Banjarbaru City Inspectorates.

9. Monitoring has a significant effect on the performance accountability of government agencies in Banjarbaru City Inspectorates.

10. Variables that budget planning, budget implementation, budget reporting, performance evaluation, control environment, risk assessment, control activities, information and communication and monitoring simultaneously have an effect on the performance accountability of agencies in Banjarbaru City Inspectorates

\section{References:}

Aguinis, H. (2009) Performance Management (2th ed). Person Education. Inc: Prentice Hall.

Aidintya, Raissa dkk (2016). Pengaruh Anggaran Berbasis Kinerja Terhadap Akuntabilitas Kinerja Intansi Pemerintah Pada Satuan Kerja Perangkat Daerah Kabupaten Magelang. Yogyakarta; Universitas Atma Jaya

Arens, Alvin A, Elder, Randal J, \& Beasly, Mark S. (2011). Auditing and Assurance Services, An Integrated Approach (13thed). Pearson Prentice Hall; New Jersey.

Arif, Lola dkk. 2017. Pengaruh Kompetensi dan Sistem Pengendalian Internal Terhadap Akuntabilitas Kinerja Instansi Pemerintah.Palu; STIE Panca Bhakti

Bayu, Fajar dkk (2016). Faktor-Faktor Yang Mempengaruhi Akuntabilitas Kinerja Instansi Pemerintah . Semarang; Universitas Negeri Semarang.

COSO ERM Integrated Framework. (2004) by the Committee of Sponsoring Organizations of the Treadway Commission.

COSO, (2013) Internal Control - Integrated Framework, Defining Issues, No. (13-26), U.S

Darwanis, Sephi, Chairunnisa, (2013) Akuntabilitas Kinerja Instansi Pemerintah, Aceh: Universitas Syiah Kuala.

Ghozali, Imam, (2015) Aplikasi Analisis Multivariate Dengan Program SPSS, Edisi Keempat, Semarang:Universitas Diponegoro.

Halidayati, Ira. (2014) Pengaruh Pengawasan Internal, Pengawasan Eksternal dan Implementasi Anggaran Berbasis Kinerja Terhadap Kinerja Pemerintah Daerah.Padang; Universitas Negeri Padang

Hannum. (2013). Hubungan antara Pengendalian Internal Dengan Akuntabilitas Kinerja Instansi Pemerintah (Dinas Pendapatan Provinsi Jawa Timur. Surabaya; Universitas Airlangga

Haspiarti. (2012). Pengaruh Penerapan Anggaran Berbasis Kinerja Terhadap Akuntabilitas Kinerja Instansi Pemerintah, Skripsi; Makasar, Universitas Hasanuddin

Indra Bastian. (2006). Akuntansi Sektor Publik: Suatu Pengantar.Jakarta: Erlangga

Institute of Internal Auditors, (2012) "International Standards for the Professional

Practice of Internal Auditing (Standards). Institute of Internal Auditors

Kaltsum, Ummu dkk (2013). Pengaruh Kejelasan Sasaran Anggaran Terhadap Akuntabilitas Kinerja Instansi Pemerintah Melalui Sistem Pengendalian Intern sebagai Variabel Intervening. Semarang; Universitas Diponegoro

Kementrian Keuangan. (2009) Anggaran Berbasis Kinerja (Bagian I). diakses 2014 dari World http://www.anggaran.depkeu.go.id/webprint-list.asp?Contentld $=628$

LAN dan Badan Pengawas Keuangan dan Pembangunan, (2000) Pedoman Penyusunan Pelaporan Akuntabilitas Kinerja Instansi Pemerintah, Jakarta: Lembaga Administrasi Negara dan BBK

LAN, (2009) Manajemen Kinerja, Jakarta: Lembaga Administrasi Negara.

Mahyudin, Ifdol. (2013) "Pengawasan Internal/Pengendalian Internal", Journal of Microfinance, Jakarta.

Malgwi, A.A., Angus, O.U. (2012) "Budget in Nigerian Public Sectorll. International Journal of Finance and Accounting. I (2), 1-6.

Malik, Abdul, (2013) Pengaruh Transparansi dan Akuntabilitas Pengelolaan Anggaran Belanja Terhadap Kinerja Karyawan di PT Citra Transpor Nusantara, Jakarta: Universitas Mercu Buana.

Muda, Taufik Djundjung. (2005). Pengaruh Anggaran dan Pelaksanaan Anggaran Berbasis Kinerja terhadap Akuntabilitas Kinerja Sekretariat Kotamadya Jakarta Selatan. Jawa Barat; Universitas Padjajaran

OECD. (2004) "The Legal Framework for Budget System". OECD Journal on Budgeting.Volume 4 No. 3. 
Rahmat, Isvihana Siti Badriah. (2012) Pengaruh Pengendalian Intern dan Audit Kinerja Terhadap Akuntabilitas Publik Pada Pemerintah Kota Bandung, Bandung: Universitas Komputer Indonesia.

Sekaran, U. (2006) Metode Riset Bisnis. Jakarta: Salemba Empat

Sugiyono (2009) Metode Penelitian Kuantitatif, Kualitatif dan R \& D, Bandung: Alfabeta.

Sugiyono. (2005). Metode Penelitian Bisnis. Bandung: Alfabeta.

Sugiyono. (2011). Statistika Untuk Penelitian. Bandung: Alfabeta.

Triyanto, Haerul (2017), Pengaruh Kompetensi Sumber Daya Manusia, Pengendalian Internal, Pemanfaatan Teknologi Informasi dan Peran Inspektorat Daerah Terhadap Kualitas Laporan Keuangan
Daerah, Yogyakarta; Universitas Muhammadiyah Yogyakarta.

The Institute Internal Auditors, The Standards For The Professional Practice of Internal Auditing (SPPIA), 2002.

Wahdatul, Laura, dkk (2016). Pengaruh Anggaran Berbasis Kinerja Dan Sistem Pelaporan Keuangan Terhadap Akuntabilitas Kinerja Instansi Pemerintah Kabupaten Bandung, Bandung; Universitas Telkom

Wibiseno, Seto.(2018).Pengaruh Penerapan Anggaran Berbasis Kinerja Terhadap Akuntabilitas Kinerja Instansi Pemerintah. Surabaya;Sekolah Tinggi Ilmu Ekonomi Indonesia.

Young, R.D. (2003) Performance-Based Budget System. USC Institute for Public Service and Policy Research. 